\title{
PARTISIPASI MASYARAKAT DALAM PROGRAM KONSERVASI MALEO (Macrocephalon maleo) DI DESA MATAINDO, KECAMATAN PINOLOSIAN TENGAH, KABUPATEN BOLAANG MONGONDOW SELATAN
}

\author{
Balobahani Balantukang \\ Joachim N.K. Dumais \\ Ribka M. Kumaat
}

\begin{abstract}
The objective of this study is to know the shape and the role of level of community participation in conservation programs Maleo (Macrocephalon maleo) in Mataindo Vilage, the research was conducted in Mataindo Vilage, sub distric Pinolosian Tengah, districs Bolaang Mongondow Selatan. The data collection done by way interview. To specify the of sample to be interview are using the method simple random sampling. That the sampling of community randomly. With the total sample of 20 of respondents is obtained. Respondents interviewed were respondents lived 20 - 40 years old, age 41 - 50 years old, and 51 years and older. Mataindo village directly adjacent to the village Torosik in the east, west to the village Lungkap, south Maluku Sea, and north to the village of North Mataindo. The total area of the village of Mataindo is \pm $3500 \mathrm{~m}^{2}$ of the area of the District Middle Pinolosian. At this stage of planning with a form of activity following the meeting, to provide suggestion/ ideas, and get involved in decision making and implementation phase in the form of activity of making hathceries (nesting place) and plantation product (post-harvest) as well as monitoring activities. Based on the role of the level of community participation in the in conservation program maleo in Mataindo for village the planning, implementation and monitoring of are categorized be in between the active enough and activie.
\end{abstract}

Key words: Community the participation, Conservation Programs Maleo, forms and levels of participation.

\begin{abstract}
ABSTRAK
Tujuan dari penelitian ini adalah untuk mengetahui bentuk dan tingkat partisipasi masyarakat dalam program konservasi maleo (Macrocephalon maleo). Penelitian dilakukan di Desa Mataindo, Kecamatan Pinolosian Tengah, Kabupaten Bolaang Mangondow Selatan. Pengambilan data dilakukan dengan cara wawancara tatap muka. Pemilihan sampel yang akan diwawancara digunakan metode simple random sampling atau pengambilan sampel secara acak pada anggota masyarakat di lokasi penelitian sebanyak 20 responden. Responden yang diwawancarai adalah responden dibedakan dalam kelompok yang berumur 20 - 40 tahun, umur 41 - 50 tahun, dan 51 tahun ke atas. Pada penelitian ini program konservasi dikelompokan menjadi 3 tahap, yaitu tahap perencanan, pelaksanaan, dan monitoring. Tahap perencanaan berupa kegiatan mengikuti pertemuan, menyampaikan saran/ide, dan terlibat dalam pengambilan keputusan. Tahap pelaksanaan berupa kegiatan pembuatan hatcheries (bangunan peneluran) yang terletak pada lokasi yang semula merupakan perkebunan milik masyarakat yang telah dibeli oleh lembaga Wildlife Conservation Society Indonesia Program dan Pelestarian Alam Liar dan Satwa (WCS-IP dan PALS) untuk dijadikan nesting ground. Kegiatan selanjutnya adalah kegiatan monitoring berupa pemantauan dilokasi nesting ground Maleo. Berdasarkan tingkat partisipasi masyarakat dalam program konservasi Maleo di Desa Mataindo pada tahap perencanaan, tahap pelaksanaan dan monitoring secara menyeluruh berada pada kategori diantara cukup aktif dan aktif.
\end{abstract}

Kata kunci: Partisipasi Masyarakat, Program Konservasi Maleo, Bentuk dan Tingkat Partisipasi 


\section{PENDAHULUAN}

\section{Latar Belakang}

Burung Maleo (Macrocephalon maleo) merupakan satwa endemik Sulawesi yang saat ini hanya dapat dijumpai di Sulawesi bagian Utara, Tengah dan Tenggara. Maleo termasuk dalam suku megapoda memiliki bulu berwarna hitam atau coklat, ukuran kepala kecil, dan berkaki besar. Maleo bertelur di dalam lubang yang telah digalinya di pasir maupun di tanah gembur yang dihangatkan oleh panas bumi atau sinar matahari. Maleo akan menggali lubang dengan kedalaman yang sesuai dengan temperatur yang cocok untuk menetaskan telur berukuran besar, yang jika dibandingkan dengan ukuran tubuhnya. (Teguh $e t$ al 2001).

Populasi Maleo diperkirakan menurun tiap tahunnya disebabkan oleh kerusakan habitat akibat pembukaan lahan pertanian oleh masyarakat dan gangguan predator alami, perburuan dan pengambilan telur oleh manusia, ini merupakan ancaman terbesar terhadap kelestarian Maleo (Christy dan Lentey, 2002). Ancaman kepunahan Terhadap Burung Maleo disebabkan oleh manusia, maka maleo dilindungi oleh pemerintah Indonesia melalui Peraturan Pemerintah No. 7 Tahun 1999. Tentang Jenisjenis Satwa dan Tumbuhan yang Dilindungi.

Pada level Internasional maleo ditetapkan sebagai salah satu jenis satwa yang dilindungi oleh CITES (The Convetion on International Trade in Endangered Spesies of Wild Fauna and Flora) dengan status Appendix I (dilarang untuk diperdagangkan), dan oleh IUCN (International Union For Conservation Natural Resources) dikategorikan terancam punah (Endangered), yang berarti sedang menghadapi resiko tinggi akan punah dalam waktu yang dekat.

Strategi program konservasi maleo yang dilakukan oleh lembaga Wildlife Conservation Society-Indonesia Program (WCS-IP) dan Pelestarian Alam Liar dan Satwa (PALS) pada tahun 2013 dengan melibatkan masyarakat lokal dipandang lebih efektif dibandingkan dengan konservasi satu arah yang hanya melibatkan pemerintah untuk melindungi dan melestarikan burung maleo agar tehindar dari ancaman kepunahan.
Kawasan perlestarian Burung Maleo terletak di Desa Mataindo, Kecamatan Pinolosian Tengah, Kabupaten Bolaang Mongondow Selatan, tepatnya berada pada area pesisir pantai yang disebut "Tanjung Binerean" yang memiliki kondisi yang mendukung sebagai lokasi peneluran dan penetasan bagi 182 anak maleo dewasa keluar dari sarang. Namun disayangkan, Tanjung Binerean merupakan area perkebunan masyarakat yang bukan kawasan yang dilindungi sampai tahun 2008. Masalah ini telah mengundang perhatian lembaga nonpemerintah (WCS-IP dan PALS) untuk mengembangkan program pelestarian maleo di Tanjung Binerean, Desa Mataindo. Menurut (Honowu, 2013). Melalui program ini pemerintah desa dan masyarakat diharapkan terlibat dalam usaha pelestarian maleo.

Berbagai upaya konservasi telah dilakukan oleh pemerintah maupun lembaga non-pemerintah baik dari dalam maupun dari luar negeri untuk melindungi dan melestarikan Burung Maleo agar terhindar dari ancaman kepunahan. Untuk itu melalui penyuluhan ke masyarakat Desa Mataindo telah dilaksanakan. Hal ini untuk meningkatkan kesadaran masyarakat akan pentingnya program konservasi penyelamatan situs peneluran maleo dan telur maleo itu sendiri. Maka perlu adanya bentuk partisipasi dan tingkat partisipasi masyarakat, yang dimaksud sesungguhnya adalah keikutsertaan mulai dari tahap perencanaan, tahap pelaksanaan serta kegiatan monitoring dengan tingkat partisipasi masyarakat dalam program konservasi maleo.

\section{Pengertian Konservasi}

Kata konservasi berasal dari Bahasa Inggris, Conservation, yang kata dasar to conserve dan artinya melindungi dari hilang atau rusak. Jadi konservasi alam dapat di artikan sebagai hal yang berkaitan dengan upaya melindungi dari kehilangan atau kerusakan. (Teguh et al, 2006) pengertian konservasi mengandung tiga aspek, yaitu:

1) Perlindungan terhadap sistem penyangga kehidupan.

2) Pengawetan dan pemeliharaan keanekaragaman hayati, dan

3) Pemanfaatan secara lestari. 
Beberapa cara yang ditempuh untuk mencapai tujuan konservasi yaitu:

1) Menetapkan kawasan-kawasan konservasi (atau konservasi in situ, yaitu konservasi di habitat aslinya).

2) Menetapkan peraturan-peraturan yang mendukung.

3) Melakukan penakaran (atau konservasi ex situ, yaitu konservasi di luar habitat aslinya).

4) Mengawasi peredaran jenis-jenis yang dilindungi.

Penetapan kawasan konservasi maupun jenis yang dilindungi dilakukan oleh pemerintah. Penetapan dilakukan setelah ada pengusulan yang berdasarkan hasil penelitian baik oleh pemerintah maupun oleh pihak swasta seperti penelitian lembaga yang berkompentensi.

\section{Kawasan Konservasi}

Kawasan konservasi yang secara khusus diperuntukan bagi perlindungan alam. Kawasan ini umumnya berupa habitat alami di darat maupun di laut yang dibiarkan liar dan tidak terganggu. Berdasarkan Undang-Undang No. 5 Tahun 1990, kawasan konservasi di Indonesia dibagi atas Kawasan Suaka Alam dan Kawasan Pelestarian Alam: masing-masing dibagi lagi atas beberapa kategori sebagai berikut :

1. Kawasan Suaka Alam, terdiri dari :

1) Cagar Alam

Kawasan yang dilindungi karena mempunyai kekhasan tumbuhan, satwa, dan ekosistem. Di dalamnya dapat dilakukan kegiatan yang terkait dengan penelitian, ilmu pengetahuan, dan pendidikan, tetapi tidak untuk kegiatan wisata dan rekreasi. Contoh: Cagar Alam Tangkoko (Kota Bitung).

2) Suaka Margasatwa

Kawasan yang dilindungi kerena mempunyai ciri khas berupa keanekaragaman atau keunikan jenis satwa. Di dalamnya dapat dilakukan untuk kepentingan penelitian dan pengembangan, ilmu pengetahuan, pendidikan, wisata terbatas, dan kegiatan lainya yang menunjang budidaya. Contoh: Suaka Margasatwa Karakelang (Kabupaten Talaud).
2. Kawasan Pelestarian Alam, terdiri dari:

1) Taman Nasional

Kawasan yang dilindungi karena mempunyai ekosistem asli yang dikelolah dengan sistem Zonasi dan dimanfaatkan untuk tujuan penelitian, ilmu pengetahuan, pendidikan, menujang budidaya, pariwisata dan rekreasi. Zona inti, zona rimba, zona pemanfaatan, dan zona lain sesuai dengan keperluan. Contoh: Taman Nasional Bunaken (Kota Manado).

2) Taman Hutan Raya

Kawasan yang dilindungi untuk tujuan koleksi tumbuhan dan satwa yang alami atau buatan, jenis asli atau bukan asli, yang dimanfaatkan bagi kepentingan penelitian, ilmu pengetahuan, pendidikan, menujang budidaya, budaya, pariwisata dan rekreasi. Contoh: Taman Hutan Rakyat Bukti Seoharto (Kalimantan).

3) Taman Wisata Alam

Kawasan yang dilindungi terutama untuk pariwisata dan rekreasi alam. Di dalamnya dapat dilakukan kegiatan untuk kepentigan penelitian, ilmu pengetahuan, pendidikan, menujang budidaya dan budaya, disamping itu untuk kegiatan wisata alam.

4) Cagar Biosfer

Kawasan yang terdiri dari ekosistem asli, ekosistem unik dan telah mengalami degradasi yang keseluruhan unsur alamnya dilindungi dan dilestarikan bagi kepentingan penelitian dan pendidikan. Contoh: Taman Nasional Lorentz (Papua).

\section{Jenis Fauna dan Satwa yang dilindungi}

Jenis-jenis yang dilindungi terdiri dari tumbuhan dan hewan yang berada dalam bahaya kepunahan atau populasinya jarang. (Teguh et al, 2006) Jenis-jenis ini diterapkan secara resmi oleh pemerintah, dan terdaftar yang dipakai saat ini adalah lampiran Peraturan Pemerintah No. 7 Tahun 1999. Lampiran ini nama-nama jenis dan famili satwa dan tumbuhan dilindungi. Perlindungan jenis menurut hukum Indonesia bermakna bahwa:

1) Terhadap jenis-jenis tumbuhan yang dilindungi berlaku larangan untuk mengambil, menebang, memiliki, merusak, memusnahkan, memelihara, 
mengangkut, dan memperniagakan, baik yang utuh maupun bagian-bagiannya: dalam keadaaan hidup.

2) Terhadap jenis-jenis satwa yang dilindungi berlaku larangan untuk menangkap, melukai, membunuh, menyimpan, memiliki, memelihara, mengangkut, dan memperniagakan, baik yang utuh maupun bagian-bagiannya (kulit, tulang, telur), dalam keadaan mati.

\section{Kerjasama Internasional}

Salah satu ancaman yang dihadapi keanekaragaman hayati yaitu, perdagangan ilegal. Perdagangan seperti ini tidak hanya terbatas di dalam wilayah Indonsia tetapi juga diantara negaranegara. Untuk menghadapi hal tersebut, telah dibuat konvensi internasional tentang perdagangan flora fauna terancam, yaitu CITES (Convetion of Internasional Trade in Endangere Species of Wild of Fauna and Flora). Dalam konvensi ini (Teguh, et al, 2006), jenis-jenis satwa dan tumbuhan dikategorikan menurut Appendix atau Lampiran, semua perdagangan satwa antar negara harus mengacu pada Appendix ini :

1) Appendix I, berisi daftar jenis-jenis yang berada dalam bahaya sehingga perdagangan terhadapnya dilarang.

2) Appendix II, berisi daftar jenis yang terancam sehingga perdagangan terhadapnya dikontrol dengan ijin.

3) Appendix III, berisi daftar jenis yang untuk perdagangannya dibutuhkan ijin ekspor dari negara asal.

\section{Klasifikasi dan Karateristik Maleo Maleo (Mac- rocephalon maleo)}

Burung maleo dapat diklasifikasikan kedalam

: Kingdom Animalia, Filum Chordata, Anak filum Vertebrata, Kelas Aves, Ordo Galliformes, Sub ordo Gali, Family Megapodiidae, Sub family Cracoidae, Genus Macrocephalon, Species Macrocephalon maleo (Baker dan Butchart, 2000). Megapodiidae merupakan salah satu Suku Burung yang terdapat dalam Galliformes. Burung-burung yang terdapat dalam suku ini disebut juga burung gosong. Family Megapodiidae yang ada di wilayah IndoAustralia terdiri atas 5 jenis. Maleo berukuran se- dang, dengan panjang sekitar $55 \mathrm{~cm}$. Burung ini memiliki bulu berwarna hitam, kulit sekitar mata berwarna kuning, iris mata merah kecoklatan, kaki abu-abu, paru dan bulu sisi bawah berwarna putih kemerahjambuan (Ma'dika et al, 2001). Di atas kepalanya terdapat tonjolan atau jambul keras berwarna hitam.

Populasi satwa endemik Indonesia ini hanya ditemukan di hutan tropis dataran rendah pulau $\mathrm{Su}-$ lawesi. Maleo bersarang di daerah pasir yang terbuka, dan daerah sekitar pantai, gunung berapi dan daerah-daerah yang hangat dari panas bumi atau sinar matahari untuk menetaskan telurnya yang berukuran besar, mencapai lima kali lebih besar dari telur ayam (Tasirin et al, 2007).

\section{Perilaku Bertelur}

Penggalian lubang peneluran oleh maleo jantan dilakukan pada pagi hari antara pukul 07:00 - 09:00 atau antara pukul 14:00 - 15:00 pada siang hari (Jolanda et al. 2002). Kemudian maleo betina meletakan telurnya di lubang tersebut dan menimbunnya dengan tanah bekas galian.

Gambar 1. Menunjukan sebagian dari proses tersebut. Setelah telur diletakan dan di timbun dengan aman, maleo betina bersama pasangannya terbang untuk beristirahat di cabang-cabang pohon dekat lokasi peneluruan dan mencari makanan untuk memulihkan tenaganya.

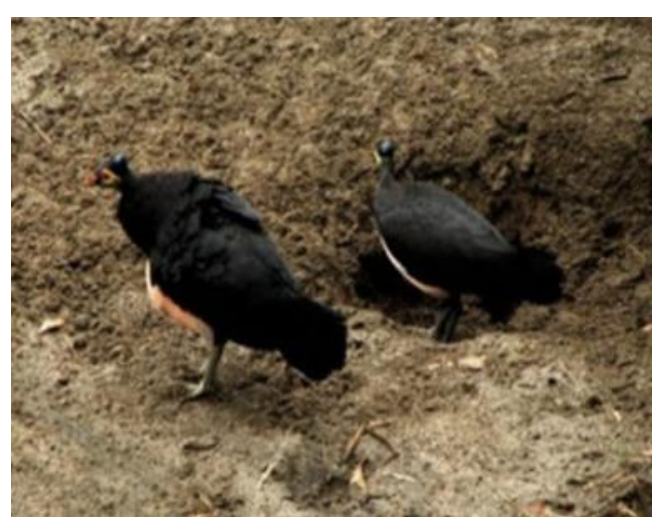

Gambar 1. Maleo mengubur telurnya di dalam tanah yang mengandung panas bumi. () WCS/Iwan Hunowu

Induk maleo tidak pernah mengawasi atau mengusik telur yang telah diletakannya sampai akhirnya menetas sendiri dengan bantuan panas ma- 
tahari atau panas bumi. Musim bertelur maleo di daerah pedalaman berlangsung pada bulan Oktober sampai April sedangkan di pantai berlangsung antara bulan Juni sampai September (Argeloo, 1991).

\section{Partisipasi Masyarakat}

Partisipasi menurut Slamet (1994) adalah sebagai keterlibatan aktif dan bermakna dari massa penduduk pada tingkatan-tingkatan yang berbeda yaitu: (a) didalam proses pembentukan keputusan untuk menentukan tujuan-tujuan promasyarakat dan pengalokasian sumber-sumber untuk mencapai tujuan tersebut (b) pelaksanaan program-program secara sukarela, dan (c) pemanfaatan hasil-hasil dari suatu program atau proyek. Oleh karena itu, pelibatan pada proses-proses perencanaan dan pelaksanaan. Partisipasi merupakan suatu proses yang aktif, yang mengandung arti bahwa orang atau kelompok yang terkait, inisiatif dan menggunakan kebebasan untuk melakukan hal itu.

Selain itu partisipasi juga merupakan keterlibatan sukarela oleh masyarkat dalam pembangunan diri, kehidupan, dan lingkungan mereka (FAO, 1989). Partisiapasi menurut (Adisasmita, 2006) adalah keterlibatan anggota masyarakat dalam pembangunan, meliputi kegiatan dalam perencanaan dan pelaksanaan (implementasi) program/proyek pembangunan yang dikerjakan oleh masyarakat lokal.

\section{Jenis Partisipasi Masyarakat}

Menurut (Sutami, 2009) dikemukakan bahwa jenis-jenis partisipasi meliputi: (a) Tenaga; (b) Pikiran; (c) Pikiran dan tenaga; (d) Keahlian; (e) Barang dan uang. Dari jenis-jenis partisipasi tersebut akan dijelaskan sebagaiberikut:

1. Pikiran: pikiran merupakan jenis partisipasi pada level pertama dimana partisipasi tersebut merupakan partisipasi dengan menggunakan pikiran seseorang atau kelompok yang bertujuan untuk mencapai sesuatu yang diinginkan.

2. Tenaga: merupakan jenis partisipasi pada level kedua dimana partisipasi tersebut dengan mendayagunakan seluruh tenaga yang dimiliki secara kelompok maupun individu untuk mencapai sesuatu yang diinginkan.
3. Pikiran dan Tenaga: merupakan jenis partisipasi pada level ketiga dimana tingkat partisipasi tersebut dilakukan bersama-sama dalam suatu kelompok dalam mencapai tujuan yang sama.

4. Keahlian: merupakan jenis partisipasi pada level keempat dimana dalam hal tersebut keahlian menjadi unsur yang paling diinginkan untuk menentukan suatu keinginan.

5. Barang: merupakan jenis partisipasi pada level kelima dimana partisipasi dilakukan dengan sebuah barang untuk membantu guna mencapai hasil yang diinginkan

6. Uang: merupakan jenis partisipasi pada level keenam dimana partisipasi tersebut menggunakan uang sebagai alat guna mencapai sesuatu yang diinginkan. Biasanya tingkat partisipasi tersebut dilakukan oleh orang-orang kalangan atas.

Keikutsertaan masyarakat adalah sangat penting di dalam keseluruhan proses pembangunan. Partisipasi masyarakat dalam program pemberdayaan selayaknya mencakup keseluruhan proses mulai dari awal sampai tahap akhir. Oleh karena itu, partisipasi publik dapat terjadi pada 4 (empat) jenjang, yaitu:

a. Partisipasi dalam tahap proses pembentukan keputusan;

b. Partisipasi dalam tahap pelaksanaan

c. Partisipasi dalam tahap pemanfaatan hasil;

d. Partisipasi dalam tahap evaluasi.

\section{Tingkat Partisipasi}

Azhari (2011), kategori tingkat partisipasi masyarakat dapat dibagi sebagai berikut :

1. Partisipasi Rendah (Nonparticipation)

Klasifikasi ini dikatakan sebagai bukan peran serta, masyarakat hanya dijadikan sebagai obyek suatu kegiatan.

2. Partisipasi Sedang (Tokenisme)

Pada Klasifikasi level ini adalah masuk ke dalam derajat penghargaan dan mengalah, yaitu saat masyarakat sudah diajak bicara tentang keinginannya dan gagasannya, tetapi keputusan apa yang akan diambil sepenuhnya berada di tangan pemerintah.

3. Partisipasi Tinggi (Citizen Power) 
Klasifikasi yang dimaksud adalah apa yang sebenarnya ada dalam gagasan Arnstein tentang peran serta masyarakat itu sendiri, yaitu pada derajat kekuasaan masyarakat dimana sudah terjadi pembagian hak, tanggung jawab dan wewenang antara masyarakat dan pemerintah dalam pengambilan keputusan. Jadi peran serta masyarakat seharusnya dirumuskan sebagai mengambil bagian dalam menentukan hal-hal yang menyangkut atau mempengaruhi hidup dan penghidupan masyarakat itu sendiri.

\section{Tahapan Partisipasi Masyarakat}

Anonim (2002), ada 7 tipologi partisipasi, yaitu :

1. Partisipasi pasif, yaitu berpartisipasi setelah diminta/undang, misalnya datang menghadiri peresmian suatu kegiatan.

2. Partisipasi dalam pemberian informasi, yaitu berpartisipasi dengan menjawab pertanyaanpertanyaan, misalnya oleh petani.

3. Partisipasi konsultasi, yaitu berpartisipasi dengan hadir diajak untuk berkonsultasi.

4. Partisipasi dengan imbalan material, yaitu berpartisipasi dengan memberikan tenaga.

5. Partisipasi funsional, yaitu berpartisipasi dengan kelompok untuk mencapai sasaran yang sudah ditetapkan (tetapi tidak dalam tahapan awal).

6. Partispasi interaktif, yaitu berpartisipasi secara interaktif, analisa bersama sudah ada.

7. Mobilisasi swakarsa, yaitu berpartisipasi dengan mobilisasi pribadi, mengambil inisiatf secara independen untuk merubah sistem lingkungan menjadi lebih baik (better farming, better income, better living, better family, better community and better enviroment).

Tahapan menurut (Sutiwi, 1986), yang membedakan partisipasi masyarakat dalam dua tahapan, yaitu: (1) Tahapan perencanaan, biasanya diwakili oleh Tokoh masyarakat atau wakil yang duduk di pemerintahan desa, (2) Tahapan pelaksanaan, dimana masyarakat ikut berpartisipasi dalam pelaksanaan program baik secara fisik maupun non fisik, dari tahapan tersebut maka masyarakat terlibat berpartisipasi dalam menikmati dan memanfaatkan hasil-hasil pembangunan yang dicapai.

\section{Program Konservasi Di Tanjung Binerean}

Wildlife Conservation Society-Indonesia Program (WCS-IP) dan Pelestarian Alam Liar dan Satwa menggunakan 6 strategi dalam mencapai tujuan, yaitu: (a) program berbasis kawasan, (b) penelitian, (c) pelatihan dan peningkatan kapasitas, (d) pengembangan model-model baru, (e) mempengaruhi kebijakan, dan (f) menghubungkan antara konservasi in-situ dan ex-situ. Berdasarkan strategi di atas, WCS-IP telah dan sedang menjalankan berbagai program (1) penelitian untuk mengumpulkan informasi, (2) pelatihan untuk meningkatkan kapasitas lokal, (3) aksi konservasi untuk memecahkan masalah, (4) penyadartahuan untuk merubah perilaku, dan (5) kebijakan untuk adanya perubahan kebijakan.

Berdasarkan uraian di atas maka penelitian ini perlu dilakukan mengingat pentingnya ketersediaan informasi dasar menyangkut partispasi masyarakat sebagai bahan pertimbangan dalam pengambilan keputusan yang berkaitan dengan program konservasi Maleo di Desa Mataindo.

\section{Rumusan Masalah}

Berdasarkan latar belakang yang dijadikan masalah dalam penelitian ini bagaimana tingkat partisipasi masyarakat dan pemerintah desa pada tahap perencanaan, pelaksanaan dalam program konservasi maleo sejak tahun 2013 sampai saat ini, di Tanjung Binerean Desa Mataindo.

\section{Tujuan Penelitian}

Mengetahui bentuk dan tingkat partisipasi masyarakat dalam tahap perencanaan, pelaksanaan dan monitoring dalam bentuk kegiatan program konservasi maleo di Desa Mataindo.

\section{Manfaat Penelitian}

Bagi penulis diharapkan dapat memberikan informasi bagi lembaga non pemerintah maupun lembaga pemerintah yang terlibat dalam partisipasi masyarakat dalam program konservasi maleo, di Tanjung Binerean Desa Mataindo Kecamatan Pinolosian Tengah Kabupaten Bolaang Mangondow Selatan. 


\section{METODOLOGI PENELITIAN}

\section{Lokasi dan Waktu Penelitian}

Adapun tempat penelitian yang dipilih yaitu Desa Mataindo Kecamatan Pinolosian Tengah Kabupaten Bolaang Mongondow Selatan. Dimana lokasi penelitian dengan lokasi situs peneluran maleo berada di pinggiran desa dengan jarak $3 \mathrm{Km}$ yang disebut "Tanjung Binerean". Waktu penelitian dilaksanakan pada bulan, Mei sampai dengan Juni 2015.

\section{Metode Pengumpulan Data}

Penelitian ini menggunakan metode survei dengan tingkat partisipasi masyarakat dalam program konservasi maleo dimana data yang digunakan adalah data Primer dan data Sekunder. Data primer diperoleh dengan wawancara langsung dengan responden. Wawancara tersebut berdasarkan daftar pertanyaan yang telah disiapkan, sedangkan data sekunder diambil dari data, Pemerintah Desa serta Lembaga konservasi Wildlife Conservation Society-Indonesia Program (WCS-IP) dan Pelestarian Alam Liar dan Satwa (PALS) yang terkait dalam penelitian.

\section{Metode Pengambilan Sampel}

Untuk pengambilan sampel dilakukan dengan menggunakan Metode Simple Random Sampling yaitu pengambilan sampel dari anggota masyarakat secara acak. Dengan jumlah sampel diperoleh sebanyak 20 responden.

\section{Konsepsi Pengukuran Variabel}

Variabel dalam penelitian ini mencakup tingkat partisipasi masyarakat dari tahap perencanaan dan tahap pelaksanaan, yakni sebagai berikut:

1. Karakteristik Responden

$>$ Tingkat pendidikan (Tidak Tamat SD, SD, SMP, SMA)

$>$ Umur responden (20 - 40 Tahun, 41 - 50 Tahun dan >51 Tahun)

$>$ Pakerjaan responden (Petani, Nelayan, Pegawai Negeri (PNS), Staf Lokal, dan Pengusaha).

2. Bentuk Partisipasi Responden :
Tahap Perencanaan

- Mengikuti pertemuan

- Menyampaikan saran/ide

- Serta pengambilan keputusan

Tahap Pelaksanaan

Partisipasi responden dalam kegiatan pembuatan hatchery, dan pengolahan hasil perkebunan.

* Monitoring

Pemantauan burung maleo di lokasi situs peneluran maleo

3. Penentuan Tingkat Partisipasi Responden

Tingkat partisipasi responden ditentukan dengan pengukuran variabel-variabel berdasarkan total skor partisipasi dari masing-masing tingkatan:

* Tahap Perencanaan

* Mengikuti Pertemuan, maximal 10x

- Sangat Aktif (4) = $8-10$

- $\operatorname{Aktif(3)}=5-7$

- Cukup Aktif (2) $=2-4$

- Kurang Aktif (1) $\quad=<2$

* Menyampaikan Saran/Ide

- Sangat Aktif =4

- Aktif = 3

- Cukup Aktif =2

- Kurang Aktif = 1

* Terlibat Dalam Pengambilan Keputusan

- Sangat Aktif =4

- Aktif = 3

- Cukup Aktif = 2

- Kurang Aktif = 1

* Tahap Pelaksanaan

$>$ Pembuatan Hatcery

- Sangat Aktif $=4$

- Aktif = 3

- Cukup Aktif = 2

- Kurang Aktif = 1

Pengolahan Hasil Perkebunan

- Sangat Aktif $=4$

- Aktif = 3

- Cukup Aktif = 2

- Kurang Aktif = 1

Monitoring

- Sangat Aktif =4

- Aktif = 3

- Cukup Aktif = 2 
- Kurang Aktif $=1$

\section{Analisis Data}

Analisis data yang digunakan dalam penelitian adalah analisis deskriptif, kualitatif yaitu, dengan pengukuran sikap menggunakan skala Likert (Riduwan dan Akdon, 2010) dan disajikan dalam bentuk tabel.

\section{HASIL DAN PEMBAHASAN}

\section{Deskripsi Daerah Penelitian}

\section{Letak Geografis, Luas Wilayah, danBatas Ad- minitrasi}

Desa Mataindo secara adminitrasi berada di Kecamatan Pinolosian Tengah yang merupakan bagian dari Kabupaten Bolaang Mongondow Selatan dengan luas keseluruhan Desa Mataindo adalah $\pm 3500 \mathrm{~m}^{\wedge} 2$. Dengan batas wilayah :

$>$ Sebelah Timur : Desa Torosik

$>$ Sebelah Barat : Desa Lungkap

$>$ Sebelah Selatan: Laut Maluku

$>$ Sebelah Utara : Desa Mataindo Utara

Berdasarkan letak dan lokasi daerah konservasi di Desa Mataindo "Tanjung Binerean" adalah lokasi peneluran maleo di mana terdapat pantai berpasir putih yang membentang sepanjang 3 kilometer. Tanjung Binerean terletak sekitar 300 kilometer ke arah Selatan dari Ibu kota Propinsi, Kota Manado, Sulawesi Utara. Secara geografis, lokasi yang juga cocok untuk kegiatan wisata alam ini membentang antara $0^{\circ} 24^{\prime} 6.32 " \mathrm{~N}$ dan $124^{\circ} 16^{\prime} 32.53 " \mathrm{E}$.

\section{Jumlah Penduduk Desa Mataindo}

Berdasarkan data profil desa jumlah penduduk Desa Mataindo, Kecamatan Pinolosian Tengah sebanyak 593 Jiwa dengan jumlah Kepala Keluarga (KK) 151 Kepala Keluarga (KK) yang menempati 2 Dusun. Tabel 1 menunjukkan bahwa jumlah penduduk laki-laki besar dari dari jumlah penduduk perempuan. Jumlah penduduk laki-laki yang lebih banyak berada di dusun II sebanyak 192 orang dan jumlah penduduk laki-laki sedikit berada di dusun I dengan jumlah 107 orang. Sedangkan jumlah penduduk perempuan paling banyak berada di dusun II sebanyak 205 orang dan paling rendah di dusun I dengan jumlah 89 orang. Untuk total jumlah penduduk terbesar berada di dusun II sebanyak 397 orang atau 66,9\% sedangkan jumlah penduduk paling sedikit berada di dusun I dengan jumlah 196 orang atau 33,0\%. Persentase jumlah Kepala Keluarga (KK) yang paling banyak berada di dusun II sebasar 97 Kepala Keluarga (KK) atau $65,1 \%$ dan yang sedikit di dusun I dengan jumlah 52 Kepala Keluarga (KK) atau 34,9\%.

Tabel 1. Jumlah Penduduk

\begin{tabular}{|c|c|c|c|c|c|c|c|}
\hline \multicolumn{7}{|c|}{ Jumlah Penduduk } & \multirow[b]{2}{*}{ Persentase } \\
\hline \multirow{2}{*}{ No } & \multirow{2}{*}{ Dusun } & \multirow{2}{*}{$\mathrm{L}$} & \multirow{2}{*}{$P$} & Jumlah & Persentase & Jumlah & \\
\hline & & & & (Orang) & $(\%)$ & $(\mathrm{KK})$ & $(\%)$ \\
\hline 1 & I & 107 & 89 & 196 & 33 & 52 & 34,9 \\
\hline \multirow[t]{2}{*}{2} & II & 192 & 205 & 397 & 66,9 & 97 & 65,1 \\
\hline & Jumlah & 299 & 294 & 593 & 100 & 149 & 100 \\
\hline
\end{tabular}

Sumber: Kantor Desa Mataindo, 2014

\section{Karakteristik Responden}

\section{Tingkat Pendidikan Responden}

Salah satu faktor yang mempengaruhi tingkat pengetahuan adalah tingkat pendidikan. Semakin tinggi latar belakang pendidikannya seseorang tentunya mempunyai pengetahuan yang luas tentang pembangunanan dan bentuk partisipasi yang dapat diberikan. Faktor pendidikan dianggap penting karena dengan pendidikan yang diperoleh seseorang lebih mudah berkomunikasi dengan orang luar, dan cepat tanggap terhadap inovasi. Pendidikan juga merupakan kebutuhan pokok bagi setiap masyarakat dalam peningkatan sumber daya manusia. Berdasarkan hasil penelitian melalui wawancara dengan respoden pada tingkat pendidikan bervariasi.

Tabel 2 menunjukkan bahwa tingkat pendidikan responden terbesar adalah dengan tingkat pendidikan SD berjumlah 8 orang atau $40 \%$, tidak tamat SD berjumlah 5 orang atau 25\%, SMP berjumlah 4 orang atau $20 \%$, dan tingkat pendidikan SMA berjumlah 3 orang atau $15 \%$. Adapun tingkat pendidikan dalam program konservasi maleo di dominasi tingkat pendidikan SD. 
Tabel 2.Jumlah Responden menurut Pendidikan

\begin{tabular}{|c|c|c|c|}
\hline \multirow{2}{*}{ No } & \multirow{2}{*}{$\begin{array}{l}\text { Pendidikan } \\
\text { Responden }\end{array}$} & $\begin{array}{c}\text { Jumlah } \\
\text { Responden }\end{array}$ & $\begin{array}{c}\text { Persentase } \\
\text { (Orang) }\end{array}$ \\
\cline { 3 - 4 } & & 5 & 25 \\
\hline 1 & Tidak Tamat SD & 8 & 40 \\
\hline 2 & SD & 4 & 20 \\
\hline 3 & SMP & 3 & 15 \\
\hline 4 & SMA & 20 & 100 \\
\hline
\end{tabular}

Sumber Data : Diolah dari data primer, 2015

\section{Tingkat Umur Responden}

Dari hasil penelitian melalui wawancara terbuka tentang partisipasi masyarakat dalam program konservasi maleo di Desa Mataindo. Perbedaan umur responden juga mempengaruhi tingkat partisipasi masyarakat di dalam masyarakat terdapat perbedaan kedudukan dan derajat senioritas, sehingga akan muncul golongan tua dan golongan muda. Produktivitas tinggi seseorang dapat dipengaruhi oleh umur yang lebih muda dengan tingkat produktivitas tinggi. Sedangkan umur $>51$ tahun degan tingkat produktivitasnya lebih rendah. Hasil penelitian di Desa Mataindo, umur responden dapat dilihat pada Tabel 3.

Tabel 3. Jumlah Responden menurut Umur

\begin{tabular}{|c|c|c|c|}
\hline & Umur & Jumlah & \\
\hline No & Responden & Responden & Persentase \\
\hline & & $($ Orang $)$ & $(\%)$ \\
\hline 1 & $20-40$ & 7 & 35 \\
\hline 2 & $41-50$ & 9 & 45 \\
\hline 3 & $>51$ & 4 & 20 \\
\hline & Jumlah & 20 & 100 \\
\hline
\end{tabular}

Sumber: Diolah dari Data Primer, 2015

Tabel 3 menunjukkan bahwa persentase terbesar pada umur 41-50 tahun yaitu 9 orang atau $45 \%$, umur $20-40$ tahun dengan jumlah 7 orang atau $35 \%$, dan tingkat umur $>51$ tahun berjumlah 4 orang atau 20\%. Tabel 3 menunjukkan bahwa jumlah responden di tingkat umur 41 - 50 tahun mendominasi dalam bentuk partisipasi pada program konservasi maleo di Desa Mataindo.

\section{Tingkat Pekerjaan Responden}

Berdasarkan hasil penelitian melalui wawancara pada responden tetang bentuk partisipasi masyarakat dalam program konservasi maleo. Ada lima jenis pekerjaan responden. pekerjaan berkaitan dengan tingkat penghasilan seseorang. Dengan demikian dapat dikatakan bahwa mata pencaharian dapat mempengaruhi partisipasi masyarakat dalam program konservasi maleo.

Hal ini disebabkan pekerjaan akan berpengaruh terhadap waktu luang seseorang untuk terlibat dalam bentuk partisipasi, misalnya dalam tahap perencanaan dan tahap pelaksanaan.

\section{Tabel 4. Jumlah Responden menurut Kategori} Pekerjaan

\begin{tabular}{|c|c|c|c|}
\hline No & Pekerjaan & $\begin{array}{c}\text { Jumlah } \\
\text { Responden }\end{array}$ & $\begin{array}{c}\text { Pers entase } \\
(\text { Orang })\end{array}$ \\
\hline & Responden & 12 & 60 \\
\hline 1 & Petani & 2 & 10 \\
\hline 2 & PNS & 4 & 20 \\
\hline 4 & Nelayan & 1 & 5 \\
\hline 5 & Staf Lokal & 1 & 5 \\
\hline & Pengusaha & 20 & 100 \\
\hline
\end{tabular}

Sumber: Diolah Dari Data Primer, 2015

Tabel 4 menunjukkan bahwa persentase jenis pekerjaan responden paling tinggi adalah petani berjumlah 12 orang atau $60 \%$, nelayan berjumlah 4 orang atau 20\%, pegawai negeri (PNS) berjumlah 2 orang atau $10 \%$, dan jenis pekerjaan paling rendah adalah staf lokal dan pengusaha masing-masing berjumlah 1 orang atau 5\%. Partisipasi responden dalam program konservasi maleo di dominasi dengan jenis pekerjaan petani.

Bentuk dan Tingkat Partisipasi Masyarakat dalam Kegiatan Program Konservasi Maleo pada Tahap Perencanaan

Dalam tahap perencanaan program konservasi maleo dibutuhkan partisipasi masyarakat sesuai kebutuhan kegiatan pada tahap perencanaan, melalui tahapan-tahapan yang ditentukan oleh pihak lembaga non pemerintah WCS-IP dan PALS mau- 
pun Pemerintah Desa dimulai dari pengalian gagasan dan ide yang dilaksanakan di Desa Mataindo. Mengenai rencana kegiatan program konservasi maleo, bentuk partisipasi dan tingkat partisipasi masyarakat dilakukan dalam tahap perencanaan. Adapun bentuk dan tingkat partisipasi masyarakat adalah keaktifan mengikuti pertemuan tentang rencana program konservasi maleo antara Lembaga Non Pemerintah (WCS-IP/PALS) dan Pemerintah Desa, dapat menyampaikan saran/ide yang berkaitan dengan program konservasi maleo serta terlibat dalam pengambilan keputusan mengenai programprogram yang berkaitan dengan pembentukkan dan pendampingan dari masyarakat.

Adapun hasil pengambilan data melalui wawancara dengan responden di Desa Mataindo bahwa bentuk partisipasi masyarakat pada tahap perencanaan dapat dilihat dalam Tabel 5.

Tabel 5. Bentuk Partisipasi Responden pada Tahap Perencanaan dalam Program Konservasi Maloe di Desa Mataindo

\begin{tabular}{|c|c|c|c|}
\hline & & Jumlah & \\
\hline \multirow[t]{2}{*}{ No } & Bentuk Partisipasi & Responden & Persentase \\
\hline & & (Orang) & $(\%)$ \\
\hline 1 & Mengikuti Pertemuan & & \multirow{3}{*}{100} \\
\hline 2 & Menyampaikan Saran/Ide & 20 & \\
\hline \multirow[t]{2}{*}{3} & $\begin{array}{c}\text { Terlibat Dalam Pengambilan } \\
\text { Keputusan }\end{array}$ & & \\
\hline & Jumlah & 20 & 100 \\
\hline
\end{tabular}

Tabel 5 menunjukkan bentuk partisipasi masyarakat dengan jumlah 20 orang atau $100 \%$. Adapun bentuk partisipasi responden mengikuti pertemuan, memberikan saran/ide serta terlibat dalam pengambilan keputusan. Melalui bentuk dan tingkat partisipasi masyarakat dalam tahap perencanaan dapat diketahui antusias masyarakat tinggi bahwa adanya program tersebut dapat menumbuhkan kesadaran masyarakat tentang pentingnya perlindungan serta pelestarian burung maleo.

Untuk melihat tingkat dan bentuk dan tingkat partisipasi masyarakat dapat dilihat pada Tabel 6.
Tabel 6. Jumlah Responden menurut Tingkat Partisipasi Masyarakat dalam Program Konservasi Maleo pada Tahap Perencanaan Berdasarkan Bentuk Partisipasi Mengikuti Pertemuan

\begin{tabular}{|c|c|c|c|}
\hline \multirow{2}{*}{ No } & Partisipasi & $\begin{array}{c}\text { Jumlah } \\
\text { Responden }\end{array}$ & $\begin{array}{c}\text { Persentase } \\
\text { (Orang) }\end{array}$ \\
\cline { 2 - 4 } & Masyarakat & 9 & 45 \\
\hline 1 & Sangat Aktif & 5 & 25 \\
\hline 2 & Aktif & 4 & 20 \\
\hline 3 & Cukup Aktif & 2 & 10 \\
\hline 4 & Kurang Aktif & 20 & 100 \\
\hline & Jumlah & & \\
\hline
\end{tabular}

Sumber: Diolah dari Data Primer, 2015

Tabel 6 menunjukkan hasil wanwancara berkaitan dengan bentuk partisipasi responden dalam program konservasi maleo pada tahap perencanaan berdasarkan tingkat partisipasi responden sangat aktif terbanyak dengan jumlah 9 orang atau $45 \%$, responden cukup aktif mengikuti pertemuan 4 orang atau 20\%. Sedangkan responden kurang aktif dalam bentuk mengikuti pertemuan dengan jumlah 2 orang atau 10\%. Adapun bentuk dan tingkat partisipasi responden pada pada tahap perencanaan dalam kegiatan mengikuti pertemuan paling tinggi dikarenakan responden antusias responden sangat tinggi dan ingin mengenal lebih dekat tetang program konservasi maleo. Pihak pemerintah desa maupun masyarakat Desa Mataindo mendukung adanya program konservasi maleo ini.

Tabel 7 menunjukkan hasil wawancara berkaitan dengan tingkat partisipasi responden pada tahap perencanaan dalam program konservasi maleo berdasarkan bentuk partisipasi responden menyampaikan saran/ide, kurang aktif terbanyak dengan jumlah 12 orang atau $60 \%$, responden cukup aktif dengan jumlah 4 orang atau $20 \%$. Sedangkan tingkat partisipasi responden sangat aktif dan aktif dengan jumlah responden masing-masing 2 orang atau $10 \%$. Tabel 7 pada tahap perencanaan berdasarkan bentuk partisipasi responden menyampaikan saran/ide dengan tingkat partisipasi responden kurang aktif dipertimbangkan berbagai alasan yang diberikan oleh responden dimana responden datang hanya mengikuti pertemuan tetapi kurang aktif dalam penyampaikan saran/ide dikare- 
nakan responden belum memahami tentang program konservasi maleo.

Tabel 7. Jumlah Responden menurut Tingkat Partisipasi Masyarakat dalam Program Konservasi Maleo pada Tahap Perencanaan Berdasarkan Bentuk Partisipasi Menyampaikan Saran/Ide

\begin{tabular}{|c|c|c|c|}
\hline \multirow{3}{*}{ No } & & Jumlah & \\
\hline & Partisipasi & Responden & Persentase \\
\hline & Masyarakat & (Orang) & $(\%)$ \\
\hline 1 & Sangat Aktif & 2 & 10 \\
\hline 2 & Aktif & 2 & 10 \\
\hline 3 & Cukup Aktif & 4 & 20 \\
\hline \multirow[t]{2}{*}{4} & Kurang Aktif & 12 & 60 \\
\hline & Jumlah & 20 & 100 \\
\hline
\end{tabular}

Sumber: Diolah dari Data Primer, 2015

Tabel 8 menunjukkan hasil wawancara berkaitan dengan tingkat partisipasi responden pada tahap perencanaan dalam program konservasi maleo berdasarkan bentuk partisipasi respoden terlibat dalam pengambilan keputusan. Dimana responden kurang aktif dengan jumlah terbanyak 16 orang atau $80 \%$, respoden sangat aktif dan cukup aktif paling sedikit masing-masing berjumlah 2 orang atau $10 \%$.

Tabel 8. Jumlah Responden menurut Tingkat Partisipasi Masyarakat dalam Program Konservasi Maleo pada Tahap Perencanaan Berdasarkan Bentuk Partisipasi Terlibat Dalam Pengambilan Keputusan

\begin{tabular}{|c|c|c|c|}
\hline \multirow{2}{*}{ No } & Partisipasi & $\begin{array}{c}\text { Jumlah } \\
\text { Responden }\end{array}$ & $\begin{array}{c}\text { Persentase } \\
\end{array}$ \\
\cline { 2 - 4 } & Masyarakat & (Orang) & $(\%)$ \\
\hline 1 & Sangat Aktif & 2 & 10 \\
\hline 2 & Aktif & - & - \\
\hline 3 & Cukup Aktif & 2 & 10 \\
\hline 4 & Kurang Aktif & 16 & 80 \\
\hline & Jumlah & 20 & 100 \\
\hline
\end{tabular}

Sumber: Diolah dari Data Primer, 2015

Tabel 8 menunjukkan tahap perencanaan dalam program konservasi maleo berdasarkan tingkat partisipasi responden yang terlibat dalam pengambilan keputusan hanya responden dengan tingkat perkerjaan Pegawai Negeri (PNS) dan Pengusaha. Dengan jumlah terbanyak kurang aktif terlibat dalam pengambilan keputusan pada tahap ini, berbagai alasan yang diberikan oleh responden dimana sebagian responden yang memiliki tingkat pendidikan Tidak Tamat SD, SD, dan SMP.

\section{Bentuk dan Tingkat Partisipasi Masyarakat da- lam Kegiatan Program Konservasi Maleo pada Tahap Pelaksanaan}

Tahap pelaksanaan merupakan tahap dimana kegiatan dengan bentuk fisik dalam bentuk dan tingkat partisipasi masyarakat dengan memberikan waktu dan tenaga dalam program konservasi maleo pada tahap pelaksanaan. Dimana dibutuhkan kerjasama antara lembaga non pemerintah dengan masyarakat pad hatcheries tahap kegiatan ini, dalam bentuk pembuatan hatchery (bangunan peneluran), dan pengelolahan hasil produksi perkebunan (hasil panen) dengan tingkat partisipasi responden sangat aktif, aktif, cukup aktif, dan kurang aktif.

Tabel 9 menunjukkan bentuk partisipasi masyarakat pada tahap pelaksanan dalam program konservasi maleo di Desa Mataindo.

Tabel 9. Bentuk Partisipasi Responden pada Tahap Pelaksanaan dalam Program Konservasi Maleo di Desa Mataindo

\begin{tabular}{cccc}
\hline No & Bentuk Partisipasi & $\begin{array}{c}\text { Jumlah } \\
\text { Responden } \\
\text { (Orang) }\end{array}$ & $\begin{array}{c}\text { Persentase } \\
(\%)\end{array}$ \\
\hline 1 & $\begin{array}{c}\text { Pembuatan } \\
\text { hatcheries di } \\
\text { lokasi nesting } \\
\text { ground }\end{array}$ & 20 & 100 \\
\hline & Jumlah & 20 & 100 \\
\hline Sumber: Diolah dari Data Primer, & 2015 &
\end{tabular}

Tabel 9 menunjukkan hasil pengambilan data melalui wawancara berkaitan dengan bentuk partisipasi responden pada tahap pelaksanaan dalam progam konservasi maleo, dari 20 atau $100 \%$ responden, melalui partisipasi masyarakat untuk menyumbangkan waktu dan tenaga pada tahap 
pelaksanaan dapat diketahui dari antusias masyarakat bahwa adanya program tersebut dapat membuka peluang kerja sama mengembangkan atau mempromosikan pelestarian alam khususnya maleo.

Untuk mengetahui bentuk dan tingkat partisipasi masyarakat dalam tahap pelaksanan juga dapat diukur dari wujud tingkat partisipasi masyarakat dalam program ini, dapat dilihat pada Tabel 10.

Tabel 10 menunjukkan hasil wanwancara berkaitan dengan bentuk partisipasi responden dalam program konservasi maleo pada tahap pelaksanaan berdasarkan tingkat partisipasi responden kurang aktif terbanyak dengan jumlah 9 orang atau $45 \%$, responden cukup aktif mengikuti pertemuan 5 orang atau 25\%. Sedangkan responden sangat aktif dalam bentuk pembuatan hatcheries dengan jumlah 4 orang atau 20\%, responden aktif berjumlah 2 orang atau $10 \%$.

Tabel 10. Jumlah Responden menurut Partisipasi Masyarakat dalam Program Konservasi Maleo pada Tahap Pelaksanaan Berdasarkan Bentuk Partisipasi Pembuatan Hatcheries

\begin{tabular}{|c|c|c|c|}
\hline \multirow{2}{*}{ No } & Jumlah & \multicolumn{3}{|c|}{} \\
\cline { 2 - 4 } & Masyarakat & $\begin{array}{c}\text { Responden } \\
\text { (Orang) }\end{array}$ & Persentase \\
\hline & Sangat Aktif & 4 & 20 \\
\hline 1 & Aktif & 2 & 10 \\
\hline 2 & Cukup Aktif & 5 & 25 \\
\hline 3 & Kurang Aktif & 9 & 45 \\
\hline 4 & Jumlah & 20 & 100 \\
\hline
\end{tabular}

Sumber: Diolah dari Data Primer, 2015

Tabel 11 menunjukkan hasil wawancara berkaitan dengan bentuk partisipasi responden pada tahap pelaksanaan dalam program konservasi, dari 20 responden yang terlibat berpartisipasi pada kegiatan pengolahan hasil perkebunan. dengan tingkat partisipasi responden sangat aktif 7 orang atau 35\%, aktif dan kurang aktif dari masingmasing berjumlah 6 orang atau 30\%. Sedangkan tingkat partisipasi paling sedikit cukup aktif dengan jumlah 1 responden atau 5\% pada bentuk partisipasi pengolahan hasil produksi perkebunan.
Tabel 11. Jumlah Responden menurut Tingkat Partisipasi Masyarakat dalam Program Konservasi Maleo pada Tahap Pelaksanaan Berdasarkan Bentuk Partisipasi Pengolahan Hasil Perkebunan

\begin{tabular}{|c|l|c|c|}
\hline \multirow{2}{*}{ No } & Partisipasi & $\begin{array}{c}\text { Jumlah } \\
\text { Responden }\end{array}$ & $\begin{array}{c}\text { Persentase } \\
\text { (Orang) }\end{array}$ \\
\cline { 2 - 4 } & Masyarakat & $(\%)$ \\
\hline 1 & Sangat Aktif & 7 & 35 \\
\hline 2 & Aktif & 6 & 30 \\
\hline 3 & Cukup Aktif & 1 & 5 \\
\hline 4 & Kurang Aktif & 6 & 30 \\
\hline & Jumlah & 20 & 100 \\
\hline
\end{tabular}

Sumber: Diolah dari Data Primer, 2015

\section{Monitoring}

Kegiatan monitoring dalam program konservasi maelo adalah pemantauan di lokasi Tanjung Binerean dan sepanjang daerah pesisir pantai di Desa Mataindo. Merupakan sebuah grid sistem yang telah di pasang untuk memonitor keberadaan maleo itu sendiri, terutama untuk memonitor keberadaan telur serta melepas anak maleo yang baru menetas setiap harinya. Berdasarkan bentuk dan tingkat partisipasi respoden pada kegiatan ini, dapat memantau dan memberikan laporan kepada pihak lembaga non pemerintah (WCS-IP / PALS) dan pemerintah desa untuk mengurangi ancaman dari perburuan dan pencurian telur maleo itu sendiri.

Tabel 12. Jumlah Responden menurut Bentuk Partisipasi Masyarakat dalam Program Konservasi Maleo pada Tahap Monitoring

\begin{tabular}{|c|l|c|c|}
\hline \multirow{2}{*}{ No } & Partisipasi & $\begin{array}{c}\text { Jumlah } \\
\text { Responden }\end{array}$ & Persentase \\
\cline { 2 - 4 } & Masyarakat & (Orang) & $(\%)$ \\
\hline 1 & Sangat Aktif & 3 & 15 \\
\hline 2 & Aktif & 5 & 25 \\
\hline 3 & Cukup Aktif & 4 & 20 \\
\hline 4 & Kurang Aktif & 11 & 55 \\
\hline & Jumlah & 20 & 100 \\
\hline
\end{tabular}

Sumber: Diolah dari Data Primer, 2015

Tabel 12 menunjukkan bentuk partisipasi masyarakat pada tahap monitorin pada program konservasi maleo di Desa Mataindo. 
Tabel 12 menunjukkan hasil bentuk dan tingkat partisipasi responden dalam program konservasi dengan kegiatan monitoring maleo. Berdasarkan tingkat partisipasi responden paling tinggi adalah kurang aktif dengan jumlah 11 responden, sementara responden sangat aktif paling rendah dengan jumlah 3 responden dalam kekgiatan pemantauan maleo.

\section{Jumlah Tingkat Partisipasi Masyarakat dalam Program Konservasi Maleo di Desa Mataindo Berdasarkan Bentuk Partisipasi pada Tahap Perencanaan, Tahap Pelaksanaan dan Kegiatan Monitoring}

Tabel 13 menunjukkan hasil penelitian tingkat partisipasi masyarakat dalam program konservasi maleo dalam bentuk partisipasi masyarakat. Berdasarkan hasil penentuan skor tingkat partisipasi sangat aktif, aktif, cukup aktif, dan kurang aktif.

Pada tahap perancanaan dengan bentuk kegiatan mengikuti pertemuan, menyampaikan saran/ide, dan terlibat dalam pengambilan keputusan dan tahap pelaksanaan dalam bentuk kegiatan pembuatan hatcery (tempat peneluran) dan pengolahan hasil perkebunan (pasca panen) serta kegiatan monitoring dalam program konservasi maleo di Desa Mataindo.

Tabel 13 menunjukkan hasil penelitian tingkat partisipasi masyarakat dalam program konservasi maelo. Digunakan empat kategori mengukur tingkat partisipasi pada tahap perencanaan dengan 3 bentuk kegiatan mengikuti pertemuan, menyampaikan saran/ide, dan terlibat dalam pengambilan keputusan, sedangkan pada tahap pelaksanaan dengan 2 bentuk kegiatan pembuatan hatchery dan pengolahan hasil perkebunan, dan bentuk kegiatan monitoring.

Pengukuran sikap Tingkat Partisipasi responden dengan Skor Sangat Aktif (4), Aktif (3), Cukup Aktif (2), Kurang Akif (1), untuk mengukur jumlah skor tingkat partisipasi pada tahap perencanaan, tahap pelaksanaan, dan monitoring.

Dimana cara pengukuran tingkat partisipasi dilakukan penjumlahan besarnya interval skor untuk menentukan kategori tingkat partisipasi masyarakat secara mneyeluruh didasarkan pada skor kategori tingkat partisipasi individu yang dikalikan dengan jumlah sampel, dengan hasil penelitian maka penjelasan tentang tingkat partisipasi masyarakat secara terperinci.

Tabel 13. Jumlah Skor Tingkat Partisipasi Masyarakat dalam Program Konservasi Maleo Berdasarkan Bentuk Partisipasi pada Tahap Perencanaan, Tahap Pelaksanaan dan Monitoring

\begin{tabular}{|c|c|c|}
\hline No & Tahap & Skor \\
\hline 1 & Perencanaan & 123 \\
\hline 2 & Pelaksanaan & 95 \\
\hline 3 & Monitoring & 37 \\
\hline & Jumlah & 255 \\
\hline
\end{tabular}

Sumber: Diolah dari Data Primer, 2015

Dengan 4 karakteristik untuk melihat tingkat partisipasi individu masing-masing dapat diberikan skor 1 sampai 4. Dimana tingkat pengukuran skor kurang aktif adalah $(3 \times 1 \times 20=60)$, untuk kategori cukup aktif adalah $(3 \times 2 \times 20=120)$, untuk kategori aktif adalah $(3 \times 3 \times 20=180)$, untuk kategori sangat aktif adalah $(3 \times 4 \times 20=240)$, dari 3 bentuk partisipasi tahap perencanaan.

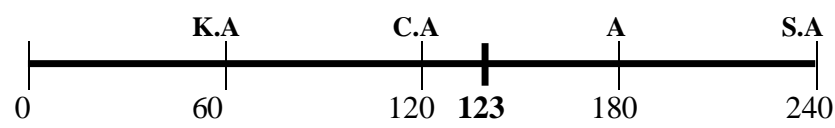

Gambar 2. Skala Capaian Tingkat Partisipasi Masyarakat Dalam Program Konservasi Maleo pada Tahap Perencanaan

Gambar 2 menunjukan capaian tingkat partisipasi masyarakat dalam program konservasi maleo pada tahap perencanaan adalah sebesar 123 atau berada pada kategori antara cukup aktif dan aktif.

Gambar 2 maka, skala capaian tingkat partisipasi masyarakat dalam program konservasi maleo pada tahap perencanaan berdasarkan bentuk partisipasi dikategorikan berada pada antara cukup aktif dengan aktif.

Sedangkan tingkat partisipasi pada tahap pelaksanaan dengan 2 bentuk kegiatan, masing- 
masing respoden dapat diberikan skor dengan kategori kurang aktif adalah $(2 \times 1 \times 20=40)$, untuk kategori cukup aktif adalah $(2 \times 2 \times 20=80)$, untuk kategori aktif adalah $(2 \times 3 \times 20=120)$, untuk kategori sangat aktif adalah $(2 \times 4 \times 20=140)$.

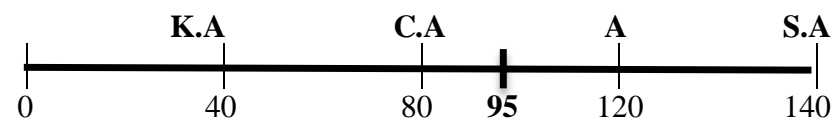

Gambar 3. Skala Capaian Tingkat Partisipasi Masyarakat Dalam Program Konservasi Maleo pada Tahap Pelaksanaan

Gambar 3 menunjukkan capaian tingkat partisipasi masyarakat dalam program konservasi maleo pada tahap pelaksanaan adalah sebesar 95 atau berada pada kategori antara cukup aktif dan aktif. Untuk tingkat partsipasi kegiatan monitoring dapat diberikan skor adalah kategori kurang aktif adalah $(1 \times 20=20)$, untuk kartegori cukup aktif adalah $(2 \times 20=40)$, untuk kategori aktif adalah $(3 \times 20=60)$, dan untuk kategori sangat aktif adalah $(4 \times 20=80)$.

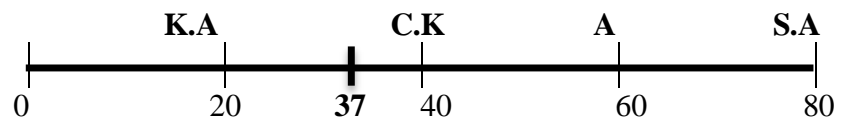

Gambar 4. Skala Capaian Tingkat Partisipasi Masyarakat Dalam Program Konservasi Maleo pada Kegiatan Monitoring

Gambar 4 menunjukkan capaian tingkat partisipasi masyarakat dalam program konservasi maleo pada kegiatan monitoring adalah sebesar 37 atau berada pada kategori antara kurang aktif dan cukup aktif.

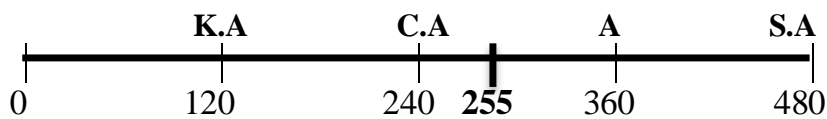

Gambar 5. Skala Capaian Tingkat Partisipasi Masyarakat

Dalam Program Konservasi Maleo pada Tahap

Perencanaan, Tahap Pelaksanaan, dan Kegiatan Monitoring

Gambar 5 menunjukkan jumlah pengukuran skor tingkat partisipasi pada tahap perencanaan, pelaksanaan, dan monitoring dapat dilihat pada Lampiran 7 total skor tingkat partisipasi masyarakat dalam program konservasi maleo. Dengan 3 bentuk kegiatan tahap perencanaan, 2 bentuk kategori pada tahap pelaksanaan, dan 1 bentuk kegiatan monitoring dengan jumlah 6 bentuk kegiatan partisipasi masyarakat dalam program konservasi maleo. Dengan 3 bentuk kegiatan, tahap perencanaan, 2 bentuk kategori pada tahap pelaksanaan, dan 1 bentuk pada bentuk kegiatan monitoring dengan jumlah 6 bentuk kegiatan. Untuk masing-masing responden dapat diberikan skor 1 sampai 4. Maksimum skor untuk kategori kurang aktif $(6 \times 1 \times 20=120)$, untuk kategori cukup aktif adalah $(6 \times 2 \times 20=240)$, untuk kategori aktif adalah $(6 \times 3 \times 20=360)$, untuk kategori sangat aktif adalah $(6 \times 4 \times 20=420)$.

Berdasarkan Gambar 5 menunjukkan capaian tingkat partisipasi masyarakat dalam program konservasi maleo pada tahap perencanaan, pelaksanaan, dan monitoring adalah sebesar 255 atau berada pada kategori antara cukup aktif dan aktif.

\section{KESIMPULAN DAN SARAN}

\section{Kesimpulan}

Tingkat partisipasi masyarakat dalam program konservasi maleo di Desa Mataindo baik pada tahap perencanaan maupun tahap pelaksanaan adalah berada pada kategori diantar cukup aktif dan aktif. Sedangkan pada kegiatan monitoring berada pada kategori diantara kurang aktif dan cukup aktif. Total dari tingkat partisipasi masyarakat pada 3 bentuk kegiatan tahap perencanaan, tahap pelaksanaan, dan monitoring adalah berada pada kategori diantara cukup aktif dan aktif.

\section{Saran}

Untuk meningkatkan kegiatan masyarakat dalam keberhasilan program konservasi maleo di Desa Mataindo untuk diperlukan dukungan dari pihak lembaga non pemerintah dan pemerintah desa dukungan dari pihak lembaga non pemerintah dan pemerintah desa. 


\section{DAFTAR PUSTAKA}

Adisasmita, R., 2006. Membangun Desa Partisipasi. Graha Ilmu. Yogyakarta.

Anonim. 2002. Membangun Partisipasi Petani. Di dalam Majalah Penyuluhan Kehutanan Kendari. Edisi 29/2002. Demak.

Argeloo, M., 1991. Maleo Coservation Project. $W W F-I C P B P$. Amsterdam.

Azhari. I. 2011. T ingkat Partisipasi Masyarakat Pada Tahap Perencanaan. Dalam Program Neighbourhood Development Studi Kasus Desa Jendi Kecamatan Selogiri Kabupaten Wonogiri, Skripsi. Fakultas Teknik Universitas Sebelas Maret Surakarta.

Baker, G.C., dan Butchart, S.H.M. (2000). Threats to Maleo Macrocephalon maleo and recommendations for its conservation. Oryx 34: 255-261.

Christy, M.J., dan Lentey. S.M, 2002. Proyek Maleo - Tahap 3 Sulawesi Utara, Indonesia, Taman Nasional Bogani Nani Wartabone, Laporan Tahun, Agustus 2001 - Juli 2002. Departemen Kehutanan (PKA) Wildlife Conservation Society - Indonesia Program. Manado.

Honowu, I. 2013. Konservasi Jenis Terancam Punah Di Tanjung Binerean. (Perkembangan Terkini Pembelian Tanah Untuk Konservasi Maleo \& Penyu) Wildlife Conservasi Society-Indonesia Program dan Pelestarian Alam dan Satwa Small PDF Sulawesi Utara. Manado.

Jolanda, M., Ante., Martin J., Christy., \& Stephan, M., Lentey. 2002. Proyek Maleo Tahap 3 Sulawesi Utara - Indonesia. Laporan Dasar Konservasi untuk Perlakuaan Telur Maleo dalam Bak Penetasan April - Agustus 2002. Laporan Untuk Departemen Kehutanan (PKA). Manado.
Ma'dika., O'Brien., Kinnaird., Butchart dan Baker. 2001. Survei Status Maleo di Taman Nasional Lore Lindu. Yayasan Jambata Preliminary Report.

Riduwan dan Akdon, 210. Rumus Dan Data Dalam Analisis Statistika. Untuk Penelitian: Administrasi Pendidikan, Bisnis, Pemerintah, Sosial, Kebijakan, Ekonomi, Hukum, Manajemen, Kesehatan. Alfabeta. Anggota IKAPI. Jawa Barat.

Setyowati, E. 2010. Partisipasi Masyarakat Dalam pengelolaan Hutan Mangrove Di Desa Surodadi Kecamatan Sayung Kabupaten Demak. Tesis. Sekolah Pascasarjana Institut Pertanian. Bogor.

Slamet, 1994. Pembangunan Masyarakat Berwawasan Peran Serta, Sebelas Maret University Press. Surakarta.

Sutiwi, E. 1986. Desa, Masyarakat dan Partisipasi Masyrakat dalam Pembangunan Desa. Tesis. Usaha Nasional. Surabaya.

Sutami, 2009. Partisipasi Masyarakat Pada Pembangunan Prasarana Lingkungan Melalui Program Pemberdayaan Masyarakat Kelurahan (PPMK) Di Kelurahan Marunda Jakarta Utara, Tesis, Universitas Diponegoro Semarang.

Tasirin, J., D. Rogi, S. Siwu, I. Honowu, E. Maneasa, dan B. Antono. 2007. Konservasi Maleo (Macrocephalon maleo) di Sulawesi. WCS-Indonesia Program Sulawesi Dan Taman Nasional Bogani Nani Wartabone. Manado.

Teguh, H., R. Manoppo, dan S. Siwu, 2001. Mengenal Beberapa Satwa Sulawesi Utara dan Gorontalo. WCS-IP Sulawesi. Manado.

Tegu, H., Adhikerana, A., Wangko. M. 2006. Keanekaragaman Hayati Kepulauan Talaud. Buku Panduan oleh Burung Indonesia 28-31. Jakarta. 
Widyastuti. Y.E. 1993. Flora-fauna Maskot Nasional dan Propinsi. (The Provincial and National Maskot of Flora and Fauna). Penebar Swadaya. Jakarta.

Yulinati. Y. 2012. Analisis Partisipasi Masya-rakat Dalam Pelaksanaan Program Nasional Pemberdayaan Masyarakat (PNPM) Mandiri Perkotaan Di Kota Solok, Artikel. Universitas Andalas Padang. 